\title{
UM CASO DE INOVAÇÃO “ACIDENTAL” EM MATÉRIA DE PENAS: A LEI BRASILEIRA DE DROGAS ${ }^{1}$
}

\author{
Alvaro P. Pires e Jean-François Cauchie \\ AN ACCIDENTAL INNOVATION CASE ON PUNISHMENT: \\ THE BRAZILIAN DRUG LAW \\ TRADUÇÃo José Roberto Xavier
}

\section{RESUMO}

ESTE TRABALHO É UMA REFLEXÃO SOBRE ALTERNATIVAS À PRISÃO E, DE FORMA MAIS GERAL, SOBRE AS COMPLEXAS RELAÇÕES ENTRE OS CONCEITOS DE PUNIÇÃO E DE INOVAÇÃO. NESSE SENTIDO, DISCUTIREMOS UM EXEMPLO CONCRETO EXTRAÍDO DA LEGISLAÇ̃̃O CRIMINAL BRASILEIRA - UM DISPOSITIVO DA NOVA LEI DE DROGAS (2006) - COM A FINALIDADE DE ENFATIZAR TANTO O INTERESSE TEÓRICO QUANTO AS QUESTÕES ÉTICAS QUE O CONCEITO DE INOVAÇÃO PENAL PODE SUSCITAR. INTRODUZINDO UMA MODIFICACCÃO EXTREMAMENTE IMPROVÁVEL RELATIVA ÀS PENAS, ESSA LEI BRASILEIRA NOS POSSIBILITARÁ DESENVOLVER AQUI NOSSA ARGUMENTAÇÃO EM SETE ETAPAS: 1) DESCREVER A MODIFICACÃO LEGISLATIVA QUE SERVIRÁ COMO PANO DE FUNDO PARA NOSSOS PROPÓSITOS; 2l APRESENTAR AS FERRAMENTAS CONCEITUAIS NECESSÁRIAS À DESCRIC̄ÃO QUE PRETENDEMOS FAZER DESSA MODIFICAC̣ÃO LEGISLATIVA; 3) INVOCAR O STATUS QUE A TEORIA DOS SISTEMAS AUTORREFERENCIAIS OUTORGA À PRODUÇÃO LEGISLATIVA; 4) CHAMAR A ATENÇÃO PARA DUAS MANEIRAS HISTORICAMENTE MARGINAIS DE CONCEITUALIZAR A PUNIÇÃO; 5) INDICAR ALGUNS MARCOS HISTÓRICOS SOBRE O CONCEITO DOMINANTE OU "NORMAL" DE PENA; E FINALMENTE 7) VOLTAR, A TÍTULO DE CONCLUSÃO, AOS CONCEITOS CENTRAIS TRATADOS EM NOSSA DISCUSSÃO.

\section{PALAVRAS-CHAVE}

RACIONALIDADE PENAL MODERNA, PUNIÇÃO, INOVAÇÃO, SISTEMA DE DIREITO CRIMINAL

\section{ABSTRACT}

THIS PAPER IS A REFLECTION ON ALTERNATIVES TO IMPRISONMENT AND, MORE GENERALLY, ON THE COMPLEX RELATIONSHIPS BETWEEN THE CONCEPTS OF PUNISHMENT AND INNOVATION. FOR THIS PURPOSE, WE WILL DISCUSS A CONCRETE EXAMPLE TAKEN FROM THE BRAZILIAN CRIMINAL LEGISLATION, A NEW DRUG LAW DISPOSITION (2006), IN ORDER TO EMPHASIZE THE THEORETICAL INTEREST AS WELL AS THE ETHICAL STAKES WHICH THE CONCEPT OF PENAL INNOVATION CAN UNDERSCORE. THIS LEGISLATION INTRODUCES A HYPER-IMPROBABLE MODIFICATION OF THE CONCEPT OF PUNISHMENT AND IT WILL THEREFORE ENABLE US TO DEVELOP OUR ARGUMENTS ALONG SEVEN POINTS: 1) TO DESCRIBE THE LEGISLATIVE MODIFICATION WHICH WILL SERVE AS THE BACKDROP TO OUR DISCUSSION; 2) TO INTRODUCE THE CONCEPTUAL TOOLS NEEDED TO DESCRIBE THIS LEGISLATIVE MODIFICATION; 3) TO ENUNCIATE THE STATUS THAT THE AUTO-REFERENTIAL SYSTEMS THEORY GIVES TO LAW MAKING; 4] TO DIRECT THE READER'S ATTENTION TOWARD TWO HISTORICALLY DEVIANT WAYS TO CONCEPTUALIZE PUNISHMENT; 5) TO INTRODUCE SOME HISTORICAL MARKERS OF THE DOMINANT CONCEPT OF PUNISHMENT (WITH RESPECT TO CRIMINAL JUSTICE); 6) TO ILLUSTRATE THE RE-STABILIZATION AND THE GENERALIZATION OF THE DOMINANT OR "NORMAL" CONCEPT OF PUNISHMENT AND, FINALLY, 7) TO COME BACK, IN CONCLUSION, ON THE CENTRAL CONCEPTS ADDRESSED IN OUR DISCUSSION.

\section{KEYWORDS}

MODERN PENAL RATIONALITY, PUNISHMENT, INNOVATION, SYSTEM OF CRIMINAL LAW

ostaríamos de fazer aqui algumas reflexões sobre os conceitos de inovação e de punição, tanto em política quanto em direito criminal. Nós o faremos a partir de um caso empírico: o de uma inovação "acidental" em matéria de penas que 
ocorreu na legislação brasileira em 2006. De uma forma esquemática, trataremos por um lado da criação de leis criminais pelo sistema político $\left(\mathrm{SPO}^{2}\right)$ e, por outro, das expectativas e sistemas de pensamento do sistema de direito criminal (SDC).

Como o SPO e o SC devem distinguir aquilo que sanciona um crime daquilo que não sanciona? Podemos dizer que a inovação remete a algo completamente diferente das eventuais respostas esperadas e institucionalizadas para essa questão. Guardemos por ora que ela aparece como uma resposta que reativa possibilidades que foram institucionalmente excluídas.

Distanciando-se das famosas respostas institucionalizadas, um observador de meados do século XIX constatava e reprovava o seguinte:

\begin{tabular}{|c|c|c|}
\hline${ }^{\circ}: 1$ & $\begin{array}{l}\text { « Na quase totalidade dos códigos modernos, } \\
\text { o extremo limite inferior da repressão } \\
\text { correcional é sempre a prisão ou a multa. } \\
\text { Aquém disso, nada! } \\
\text { O juiz tem sem dúvida a faculdade mais } \\
\text { ou menos ampla de reduzir a medida dessas } \\
\text { penas; mas, seja qual for o grau de clemência } \\
\text { que ele introduzir, elas são sempre prisão } \\
\text { e multa; ou seja, penas verdadeiras [...] } \\
\text { (Bonneville de Marsangy, 1864, 216, grifado } \\
\text { no original) }\end{array}$ & $\begin{array}{l}\text { A reprodução normal } \\
\text { das penas pelos } \\
\text { governantes }\end{array}$ \\
\hline
\end{tabular}

Se nosso observador não se referisse apenas aos limites inferiores e às infrações correcionais, ele teria provavelmente acrescentado a pena capital e certas formas de castigos corporais como o chicote (que permaneceu em vigor no Canadá e em outros lugares até meados do século XX). Essa breve introdução nos permitirá entrar agora no coração do problema.

Nossa argumentação será apresentada da seguinte maneira: 1) descreveremos a modificação legislativa que servirá de plano de fundo para nossos propósitos; 2) apresentaremos algumas ferramentas conceituais empregadas em nossa descrição; 3) diremos algumas palavras sobre o status da legislação para a teoria dos sistemas autorreferenciais; 4) chamaremos a atenção para duas maneiras marginais (déviantes) de conceitualizar a punição; 5) indicaremos alguns marcos históricos sobre o conceito dominante de punição; 6) ilustraremos a re-estabilização e a generalização do conceito dominante ou "normal" de pena; e, finalmente, 7) retornaremos, à título de conclusão, aos conceitos centrais abordados em nossa argumentação. 


\section{ILUSTRAÇÃO EMPÍRICA DE UM ACONTECIMENTO IMPROVÁVEL}

O SPO criou recentemente uma nova lei em matéria de drogas no Brasil (Lei 11.343 de 23 de agosto de 2006) ${ }^{3}$. De forma contrária à grande maioria das leis em matéria penal, essa introduz uma modificação extremamente improvável no que concerne às penas. $\mathrm{O}$ aspecto da modificação que nos interessa é independente do tema específico das drogas. O status "improvável" dessa mudança teria sido o mesmo se essa modificação tivesse acontecido com outro crime. Para nossos propósitos, limitarnos-emos ao artigo 28 dessa lei, que se encontra no capítulo III, cujo título é "Dos Crimes e das Penas". O leitor se dará conta que esse título invoca o do pequeno livro de Beccaria, Dos Delitos e das Penas (1764), embora o artigo 28 vá contradizer as expectativas da teoria da pena (dissuasão) selecionada por Beccaria. Eis o trecho do artigo que nos interessa:

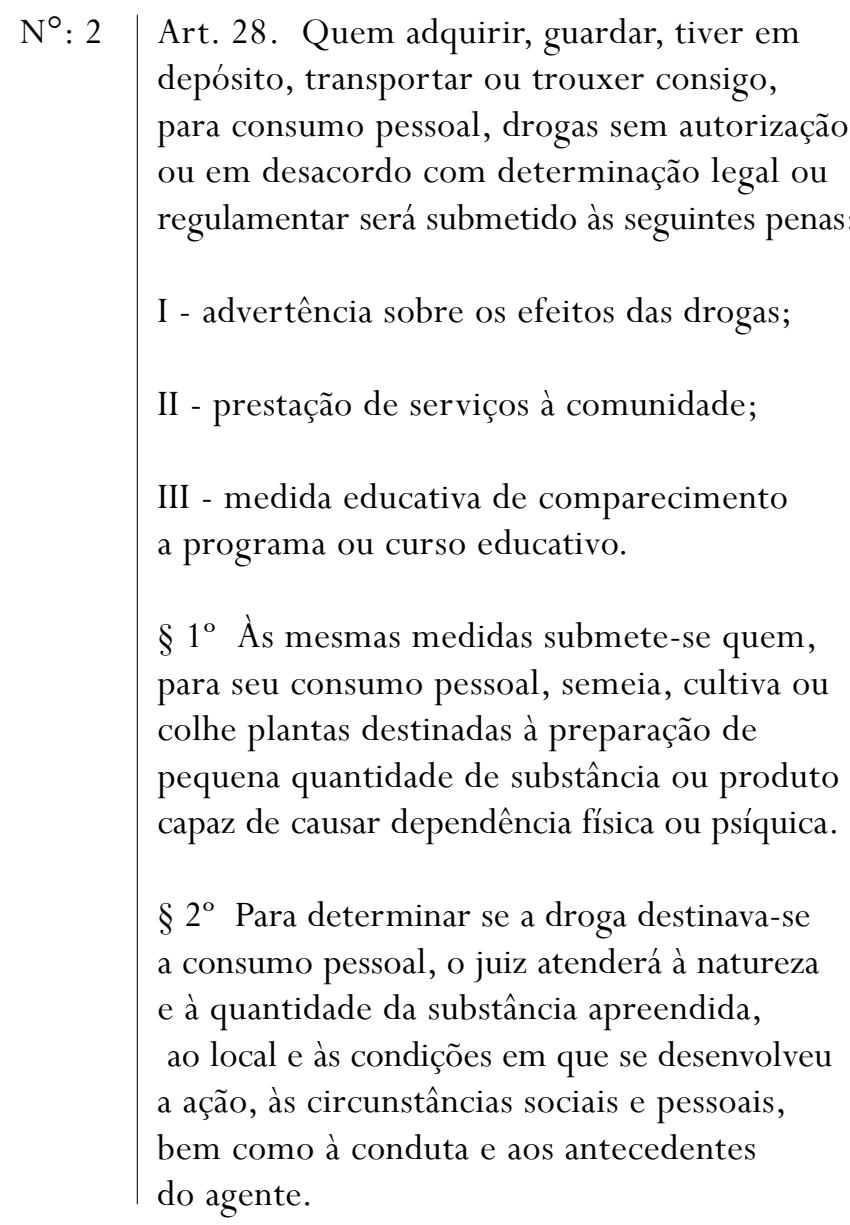

Crimes

Penas previstas

Outros crimes e mesmas penas

Critério do "consumo pessoal" 
$\S 3^{\circ}$ As penas previstas nos incisos II e III do caput deste artigo serão aplicadas pelo prazo máximo de 5 (cinco) meses.
Outra norma

de sanção

O artigo precedente (n. $\left.{ }^{\circ} 27\right)$ enuncia claramente que "as penas previstas neste capítulo poderão ser aplicadas isolada ou cumulativamente". Ele também autoriza o tribunal a substituir uma pena por outra após ouvir o ponto de vista da acusação e da defesa. No entanto, a pena de prisão parece inteiramente excluída das opções abertas ao tribunal: a escolha (cumulativa ou não) das penas deve se operar no contexto das três penas indicadas no artigo.

O leitor que está familiarizado com a maneira pela qual o SPO edita leis criminais e seleciona sanções (após a segunda metade do século XVIII), e que também está acostumado à maneira dominante pela qual a doutrina e a filosofia penal definem a punição ou a pena, compreende pelo menos intuitivamente por que qualificamos prima facie essa modificação legislativa de "acidental". Se Bonneville de Marsangy (citação n.1) ainda vivesse, ele também estaria surpreso: "Finalmente uma mudança não habitual!"

Façamos um resumo breve das diversas dimensões - mais ou menos surpreendentes dependendo do caso - desse "acontecimento acidental", dimensões às quais voltaremos mais à frente no texto:

- a pena de prisão está excluída como sanção autorizada em relação a certos crimes;

- é muito raro ver um artigo que tipifica crimes prever ao mesmo tempo (no mesmo artigo) outras penas que não a de morte, de castigo corporal, de prisão ou de multa;

- as penas que estão previstas nesse artigo (i) não têm usualmente o status jurídico de penas nas leis criminais, (ii) não são penas selecionadas e valorizadas pelas teorias modernas da pena (retribuição, dissuasão, neutralização e o primeiro paradigma da teoria da reabilitação);

- as penas selecionadas não correspondem de forma plena ao conceito de pena que sustenta que uma "verdadeira pena" exige da autoridade a intenção visível de querer infligir um sofrimento ou um mal ao infrator ${ }^{4}$.

- as penas previstas neste artigo também não correspondem de forma plena àquelas que a doutrina criminal (ou a sociologia) pensa quando sustenta que "o crime se define pela pena".

Certamente, algumas dessas dimensões, consideradas isoladamente, são menos surpreendentes. Por exemplo, há leis criminais que excluem a prisão para selecionar exclusivamente a multa. "Excluir a prisão" não é então um acontecimento tão raro assim. Mas a prisão não cede aqui o seu lugar para a multa. Esta também está ausente. Essa lei ainda tem outros aspectos surpreendentes: ela exclui a prisão e a multa referindo-se a um "crime" no sentido jurídico estrito de uma categoria particularmente 
grave de infrações criminais (em oposição a uma contravenção ou uma infração administrativa). As penas previstas aqui não são justamente penas clássicas como a multa ou a prisão, mas sim penas que não têm usualmente o status jurídico de penas criminais. Essa seleção pode ser considerada então como “altamente improvável” na prática legislativa ocidental moderna (criação de sanções criminais).

A reação do SDC, por meio da doutrina, a essa mudança legislativa foi, por razões profissionais, quase imediata ${ }^{5}$. Após a aprovação da lei, os penalistas referiram-se imediatamente a esse artigo para falar de descriminalização ou de despenalização das drogas no que concerne aos comportamentos indicados (citação n.2). Talvez a reação tenha sido de fato um pouco apressada, carecendo assim de uma elementar prudência. Mas como foi possível se falar em descriminalização de despenalização? Em qual sentido, ou em relação a qual expectativa, teria havido uma descriminalização ou despenalização?

A resposta não se encontra no texto da lei. Com efeito, se retornarmos ao título do capítulo em que se encontra o artigo problemático, lemos claramente "dos crimes e das penas”. Na perspectiva da lei, esse capítulo deve então ser entendido como se referindo a "verdadeiros crimes" e "verdadeiras penas". O artigo não autoriza, por exemplo, a posse e o uso pessoal de drogas. É justamente isso que deploram outros penalistas. Do ponto de vista da lei, o termo descriminalização é completamente inapropriado.

$\mathrm{O}$ artigo também não revoga as penas para esses crimes. Pelo contrário, ele estipula que o indivíduo pego nas situações indicadas pode sofrer as "penas" enumeradas nos pontos I, II e III do dispositivo ${ }^{6}$. Podemos então falar em despenalização? Em oposição à situação precedente, existe sem dúvida uma redução de pena. Um observador pode empregar o termo despenalização para indicar essa redução, mas o termo permanece assim ambíguo e impreciso, pois deixa-se entender que não existem mais penas para esses crimes. Se, de forma mais forte, falamos de despenalização para significar que esses crimes efetivamente não possuem mais penas, a afirmação é falsa. Afinal, ela não resiste a uma confrontação com o documento legislativo: este indica explicitamente as penas que se aplicam às condutas que são enumeradas.

Certamente essa discussão pode se eternizar. Um observador convencido de que as "penas verdadeiras" são apenas aquelas que mostram a intenção da autoridade de infligir um sofrimento pode pretender que o texto da lei não é a "realidade" em face da qual sua percepção deve ser confrontada. Ele pode simplesmente dizer que o legislador empregou um termo ruim para designar as sanções que ele (o legislador) selecionou. O observador constrói assim de uma outra forma o seu conceito de pena e diz que o que foi selecionado não corresponde à definição de uma "verdadeira pena". Ele pode também acrescentar que, tendo em vista que o "(verdadeiro) crime" se define por "penas verdadeiras", houve ao mesmo tempo despenalização e descriminalização. Na melhor das hipóteses, o legislador se enganou introduzindo no direito criminal "sanções" para os "crimes". 
A questão que colocamos se situa então sobre duas vertentes, uma virada para o SPO e a outra para o interior do SDC: como cada um desses sistemas vai reagir na sequência do advento desse acontecimento "acidental"? Retomemos aqui os comentários de Dubé (2007): esses sistemas vão ou não, e cada um por si, tirar proveito desse "elemento perturbador" para aprender a conceber de outra forma as sanções em direito criminal, para aprender a repensar a relação crime/pena etc.? Quais racionalidades justificadoras ou “motivacionais" eles vão selecionar ou colocar em prática? Do ponto de vista cognitivo, esse acontecimento será ou não “tratado como uma oportunidade de autocorreção” (Dubé, 2007) do político pelo político e do jurídico-criminal pelo jurídico-criminal? Num outro registro, perguntamo-nos igualmente se esse acontecimento será tratado pela sociologia como oportunidade de se autocorrigir no que concerne às suas próprias observações sobre a relação crime/pena assim como sobre a evolução do SDC.

Se o ponto de vista inicial do SDC for mantido, esse sistema não vai reter essa ocasião perturbadora enquanto oportunidade de aprendizagem (Dubé, 2007). Ele vai, ao contrário, lançar mão da maneira central de pensar do sistema e "isolar" ou "marginalizar" o acontecimento potencialmente inovador (para o SDC). Mais ainda, o observador não vai compreender esse acontecimento como sendo "inovador", mas sim como um “erro" de percurso. Em um caso tal, não ocorrerá a passagem de uma inovação ${ }^{7}$ na legislação produzida pelo SPO para uma inovação produzida pelo SDC no seu sistema de pensamento central referente às penas. As estruturas cognitivas dominantes (sistema de pensamento) desse sistema não vão se transformar; o sistema vai aprender muito pouco ou mesmo nada com a perturbação.

Consideremos aqui essa primeira reação (pois ela pode se modificar com o tempo) do SDC. Ela fala de descriminalização e de despenalização como um sinal do advento de uma irritação que derroga a reprodução normal do SPO. Um sinal que alguma coisa que não é apenas nova está doravante à disposição das operações dos dois sistemas (SPO e SDC); alguma coisa que é ao mesmo tempo nova e perturbadora, nova e desviante em relação a certas estruturas dos dois sistemas. Há assim novidades que perturbam - e outras que não perturbam - a reprodução normal das estruturas centrais do sistema. No Brasil, como dissemos, essa primeira reação à novidade perturbadora veio dos juristas porque eles vigiam de perto esse tipo de evento (criação de leis). Mas estaríamos enganados em acreditar que um político, um sociólogo ou um criminólogo fariam uma primeira leitura diferente.

Podemos pensar sobre essa modificação legislativa com a ajuda do conceito de “improvável provável” proposto por Morin (1977: 294-300). Antes da emergência desse tipo de penas perturbadoras na legislação criminal moderna, o que predomina é a improbabilidade física de um tal acontecimento. Improbabilidade não significa impossibilidade. Existe aqui uma improbabilidade "geral” (Morin, 1977) 
em conceber a lei criminal como portadora de penas desse tipo. Há também, no plano mais exigente da reflexão teórica em direito criminal, uma improbabilidade "geral" em conceber o conceito de pena como não exigindo a vontade visível de infligir intencionalmente um sofrimento ${ }^{8}$. Mas uma vez que essa improbabilidade física se atualiza apesar de sua improbabilidade, uma vez que ela é selecionada e que ela transpõe o limite da simples variação comunicacional da "organização produtora de si” (Morin, 1977: 295) para se inscrever numa estrutura central, esse improvável físico se torna um "improvável provável" para o sistema que o produz ou no sistema no qual ele se encontra. A presença desse improvável na estrutura do sistema transforma "o improvável geral" em "provável restrito" (Morin, 1977: 295). Todavia, se o sistema não se aproveita dessa ocasião perturbadora para aprender, a improvável provável retorna a uma improbabilidade geral.

\section{Algumas ferramentas conceituais para a observação E A DESCRIÇÃO}

Vamos explicitar agora certas ferramentas conceituais, algumas tiradas da teoria dos sistemas autopoiéticos. Pretendemos no caminho, sempre que isto se mostre necessário, fazer adaptações aos problemas específicos colocados por nosso tema ou pelas exigências da descrição empírica.

1. Para observar convenientemente essa modificação legislativa, vamos em primeiro lugar distinguir entre, de um lado, os acontecimentos (e as ações) e, de outro, as estruturas de ação (Luhmann, 1984). Uma das características dos acontecimentos (e das ações) é que eles não perduram no tempo. Um acontecimento, retomando os termos de Floyd Allport, é um "tudo-ou-nada indivisível” (citado por Luhmann, 1984: 263): um terremoto, o fato de me levantar da cama. A consequência é que não podemos mudar um acontecimento ou uma ação: ele pode simplesmente existir ou não, pois ele não dura tempo suficiente para ser modificado. Na sua relação com o tempo, diria Luhmann (1984: 263), “o acontecimento (ou a ação) prefere desaparecer”. A teoria dos sistemas vai então sustentar que as estruturas podem mudar em razão de sua relação com o tempo.

Como falamos de mudança legislativa e de diversos sistemas de pensamento dirigidos no sentido da ação, não voltamos nossa atenção para as ações ou para os acontecimentos isolados, mas para uma relação entre essas ações e as estruturas de ação. Se esses comentários são aceitáveis, uma "ação inovadora" (ou um acontecimento inovador) é aquele que modifica uma estrutura, que produz uma reprodução inovadora da estrutura de referência. No entanto, há, por assim dizer, diferentes "niveis de estruturas" e estruturas com diferentes graus de consistência. Podemos assim encontrar ações que produzem uma inovação sem portanto atingir 
certas estruturas mais exigentes (do ponto de vista cognitivo) ou mais distantes do plano das ações.

Acreditamos que as estruturas mais exigentes são os sistemas de pensamento centrais dos sistemas sociais (sistemas de função), suas principais "teorias da reflexão" (Luhmann, 1984). Essas estruturas cognitivas têm as seguintes características: (i) elas têm uma mais forte condensação de sentido (dimensão histórico-cultural); (ii) elas duram mais no tempo (dimensão temporal); (iii) elas têm uma maior capacidade de resistência à perturbação, ou seja, uma capacidade de se reproduzir normalmente mesmo em caso de decepção e apesar desta; e (iv) elas não se situam exclusivamente no plano dos sistemas de interação, das interações face a face.

Tomemos um exemplo concreto. Suponhamos um juiz que, sem ter à sua disposição - no contexto de uma interação face a face no tribunal - um dispositivo de sentença como o do artigo 28, deixa de aplicar uma pena de prisão e dá ao réu uma "pena de advertência". Chamemos isso de "nível 1" de emergência de uma ação inovadora. Nosso juiz pega aqui todo mundo de surpresa e perturba as expectativas estabelecidas de uma pena de prisão ou de multa. Consideremos agora dois cenários.

O primeiro cenário é aquele em que a reprodução normal rejeita uma reprodução inovadora que aconteceu. O promotor não se serve dessa ocasião para aprender. Ele recorre, consegue reverter a decisão do juiz e o acontecimento é esquecido ou lembrado apenas como um erro do tribunal. No sentido estrito, a comunicaçãoação do juiz tinha produzido uma inovação na estrutura de expectativas do sistema, mas por um tempo demasiado curto. Ela produziu, por assim dizer, uma variação comunicacional que arranhou a estrutura do sistema, sem ser selecionada. É um caso limite no qual a inovação quase desaparece com a comunicação que a criou. Uma variação que não resiste.

O segundo cenário é o de uma reprodução desviante que se instala em diferentes registros e conta com a ajuda do tempo. Falaremos de três registros: o das práticas localizadas dos tribunais (estruturas de expectativas do registro 1, mais ou menos "locais"), o da legislação (que depende no sentido forte de uma operação do sistema político) e, por último o que é mais exigente e mais condensado culturalmente, o dos conceitos e teorias do sistema que "não têm fronteiras" (sistemas de ideias generalizadas). As teorias da pena e o conceito de punição são exemplos desse registro mais denso.

Nosso segundo cenário é então o seguinte: é o próprio promotor que pede essa pena de advertência, não oferecendo recurso na sequência, prevalecendo portanto essa sentença. Outros procuradores e outros juízes de primeira instância consagram essa expectativa no plano local. Alguns casos chegam à segunda instância, sendo que algumas sentenças são confirmadas e outras não. No primeiro registro (o das "práticas locais"), uma variação comunicacional (inovação) existe e chega a tomar a forma de uma reprodução normal. Mas notemos três coisas: (i) sua duração no tempo é incerta, 
(ii) sua generalização e sua visibilidade no sistema são fracas, (iii) sua capacidade de resistência às perturbações e sua densidade cognitiva nas comunicações do sistema são igualmente frágeis. Tais variações ainda não modificam os conceitos e os grandes sistemas de pensamento do sistema. Neste registro, o conceito de pena permanece imutável. A pena de advertência continua a ser interpretada pela doutrina como uma simples "medida", uma "alternativa às penas de multa ou prisão", mas não como uma "verdadeira pena”. As teorias da pena permanecem assim as mesmas. E a legislação também não seleciona essas estruturas do primeiro registro.

Deixemos claro que, de um ponto de vista genético, o que se passa no registro 1 pode também "se espalhar" (ser selecionado) em outros registros. Mas, para tanto, outras inovações são necessárias e outros tipos de obstáculos devem ser desfeitos (se eles são cognitivos) ou superados (se eles são de outra ordem). É preciso inovar em outras estruturas, localizadas em outros níveis, até mesmo em outros sistemas de comunicação especializados (por exemplo, o SPO). No SDC, por exemplo, a doutrina e a teoria do direito devem produzir outras inovações que se relacionam com a inovação do registro 1, rever de forma autocrítica as posições precedentes, encontrar respostas aos argumentos da reprodução normal etc. Resumindo, agir em outros sistemas de pensamento mais ou menos solidamente ancorados, em estruturas cognitivas e reflexivas do sistema. Isso dá uma densidade cognitiva adicional às estruturas do registro "de base" e expande as fronteiras da inovação no interior do sistema: o conceito central de pena se modifica, novas teorias da pena são selecionadas e re-estabilizadas etc.

Lembremos todavia que a modificação (inovação) que examinamos começa (para nós $)^{9}$ com uma modificação legislativa que é uma comunicação-ação no interior do sistema político. Essa estrutura é mais visível, talvez mais durável, mas de uma densidade cognitiva bastante frágil e sem capacidade de resistência.

Como podemos ver, as estruturas de um sistema social autorreferencial não são tratadas pela teoria dos sistemas como "invariáveis". Somente os acontecimentos e as ações são invariáveis. Esses sistemas podem portanto modificar suas estruturas: eles podem aprender. Mas isso não é fácil e não pode ser “planejado" no sentido forte, pelo menos em todos os registros, e menos ainda ao mesmo tempo. O termo "estrutura" pode ser tratado no singular ou no plural, segundo o significado que se quer lhe dar ${ }^{10}$. Seu uso no plural ajuda a não reificá-lo e permite levar em conta as estruturas emergentes ou alternativas (ideias, teorias, sistemas de pensamento) já em operação de uma forma qualquer ou com um grau qualquer de recepção em um ou outro dos registros.

2. Considerando a distinção acontecimento/estrutura de ação, vamos agora nos colocar na face "estruturas de ação" (no plural aqui!) e operar outras distinções (nesta face, não na outra). Faremos assim uma distinção geral entre conjuntos de normas e sistemas de 
pensamento (ou de ideias), levando em conta que ambos servem como orientadores da ação. Faz-se necessário aqui fixar um conjunto de normas como ponto de referência, pois o conceito de inovação exige uma referência a contextos bem determinados. Uma norma é (ou não) inovadora em relação a um dado sistema, e não "em geral" (no "mundo das normas"). No nosso caso, a legislação criminal é o ponto de referência. Notemos entretanto que, no nosso caso, este contexto não é limitado por uma fronteira nacional. Essa distinção nos permitirá observar separadamente o que se passa na legislação (estrutura normativa) e o que se passa - ou poderia se passar - no plano do conceito de punição, das teorias da pena etc. (estrutura cognitiva). Esses dois tipos de estruturas têm uma temporalidade e um espaço independentes. Cada uma tem, por assim dizer, uma lógica de evolução própria, apesar dos cruzamentos e das influências possíveis nas duas direções. Essa distinção nos permitirá observar precisamente quais sistemas de pensamento são atualizados e, ao mesmo tempo, compreender o sentido de uma mudança legislativa.

3. No plano das normas, a estrutura é frequentemente objetivada "por ela própria", pelo menos no que concerne à legislação. Podemos observar isso com a ajuda de distinções como leis em vigor/projetos de lei ou leis/reivindicações ou pedidos de mudança. O observador extrai e reconstrói então esses "modelos" que, como escreve Luhmann (1984, 255), são diretamente produtos da realidade. No plano estrito da legislação, mesmo a hierarquia das leis depende de um tipo de "autodescrição do objeto" (Luhmann, 1984, 256). A legislação, enquanto forma de comunicação, é também uma estrutura "cognitivamente frágil", querendo dizer que ela não explicita os sistemas de pensamento, as diversas intencionalidades e motivações etc.

4. No plano dos sistemas de pensamento e de ideias, é preciso mobilizar outras distinções disponíveis na sociologia para descrever essas estruturas empiricamente, pois essas estruturas não se encontram tão claramente objetivadas e autodescritas pelo próprio objeto. Para tanto, vamos empregar distinções mais ou menos equivalentes como central/periférico, estabilizado/não estabilizado, dominante/alternativo, estabelecido/emergente etc. No caso específico da legislação, não precisamos dessas distinções, mas elas podem eventualmente se aplicar a certos tipos de normas ou de relação entre conjuntos normativos alternativos.

5. A distinção inovador/não inovador para avaliar uma mudança nas estruturas é difícil de conceitualizar e de empregar empiricamente. Vamos colocá-la em teste, provisoriamente, com a ajuda de certas ideias e critérios.

A mudança, para ser inovadora, deve antes de tudo perturbar a matriz de referência. "Perturbar" é um termo neutro, querendo dizer que o que perturba pode ser bom/mau segundo um outro tipo de codificação. A inovação seria então mais do que 
a simples novidade empírica de superfície, mais do que qualquer coisa que simplesmente "não estava lá antes". A "novidade de superfície", por assim dizer, pede uma compreensão que se faz exclusivamente com a ajuda do esquema antes/depois; na sequência, uma vez estabelecida, ela desaparece como novidade. A "novidade inovadora" vai além do esquema antes/depois. No limite, ela não depende solidamente desse esquema. As mudanças inovadoras têm aliás uma característica paradoxal: elas não deixam de ser inovadores imediatamente após a primeira atualização. Dito de outra forma: a reprodução desviante não se "normaliza” após "um único impacto" ou uma simples atualização num único registro. Durante um certo tempo, sua reprodução continua sendo "desviante". Finalmente, a mudança inovadora se choca aqui com obstáculos epistemológicos ou "de conhecimento", no sentido de Bachelard (1974), e deve desfazer esses nós culturais e científicos - sempre refazendo outros, caso queira durar -, expandir e resistir por sua vez a perturbações futuras.

Desenvolvamos essas três ideias.

No caso da legislação, o "mais que novidade" se traduz como a descrição de uma "resistência" ou de uma "contrariedade" que não se encontra explicitamente presente nem no tema da mudança nem ainda na legislação enquanto tal, mas mais no apoio cognitivo de sua matriz. Por exemplo, no caso do art. 28, a "resistência" indicadora de inovação não tem nada a ver com o problema das drogas nem com a ideia de querer aumentar ou reduzir uma pena. Ela remete mais a argumentos gerais do tipo: "um crime se define por uma pena e no entanto isto não é uma pena”, "com tais sanções, corremos o risco de destruir o edifício do direito criminal moderno", "quer-se descriminalizar esses crimes 'às escondidas'” etc. Argumentos que não têm um alcance específico ou temático, mas que indicam que "alguma coisa de mais profundo” está em questão. O paradoxo da inovação que permanece inovação pós-impacto se traduz pelo fato que essa "mesma" mudança pode ser transposta para outros lugares da legislação, se aplicar a outros crimes e ainda suscitar a mesma resistência, surpresa ou receio em relação ao futuro da matriz cognitiva da legislação. Enfim, essa mudança só vai adquirir uma capacidade de resistência se ela conseguir suscitar uma reflexão teórica interna ao sistema que, por sua vez, seja também inovadora (desfazer os obstáculos epistemológicos e reconstruir os conceitos e as teorias).

Isso posto, a análise científica ganha em se dar a liberdade de observar inovações que são casuais e que eventualmente não são percebidas imediatamente como "inovações" (mas apenas como "mudanças") pelo próprio sistema que as produz. Por exemplo, o SPO, produzindo o art. 28, pode muito bem não prestar muita atenção que este incomoda tanto a sua própria matriz dominante (sistema de pensamento em matéria de legislação criminal) quanto o sistema de pensamento central do SDC. E mesmo que a reação do SDC não tivesse se dado, ainda assim teria sido possível para a sociologia ver esse acontecimento como inovador se ao menos ela conhecesse o interior dos sistemas que ela observa. O simples conhecimento "do 
exterior" é insuficiente, no sentido de que a sociologia não vai levar em conta a especificidade do sistema de referência e de suas formas de pensar. O observador deve sempre mostrar em relação à qual matriz de referência, em quê e como a mudança observada é ou não inovadora.

No plano cognitivo, podemos dizer que a inovação aparece, ao menos virtualmente, como um fogo de artifício que estoura em etapas sucessivas. De um lado, (i) ela se reforça enquanto inovação, até um certo ponto, com sua "retomada" em outro ponto do sistema e, por outro lado, (ii) ela é suscetível (virtualidade) de produzir um impacto na reflexão teórica mais elaborada do sistema. Sua "retomada" não é imediatamente uma pura repetição, pois ela continua a levar mais longe a renovação da dimensão cognitiva e o questionamento das (antigas) estruturas dominantes. Podemos assim exprimi-la pela negativa: tudo se passa como se a primeira aparição fosse "ainda insuficiente" como inovação para desfazer os nós. A novidade perturbadora, em cada desdobramento subsequente, continua a chocar-se com "obstáculos epistemológicos" (Bachelard, 1974) que ela deve desfazer e reconstruir, o que obriga ainda a inovar enquanto ela se re-estabiliza e se generaliza.

O termo matriz será empregado aqui na sua acepção corrente: um molde que recebeu uma impressão particular e que permite reproduzir essa impressão em outras coisas submetidas à sua ação. No caso da legislação criminal, essa matriz tem, no primeiro plano, uma dimensão factual, pois basta a um observador "ver" um código criminal (ou as penas que são selecionadas para acompanhar os crimes na legislação) para perceber um "modelo dominante" no que concerne às penas: prisão e/ou multa. A simples "imitação" desse modelo é suficiente para reconduzir a reprodução normal, sem outra reflexão. Vai-se assim aumentar ou diminuir as penas disponíveis no modelo, substituir uma por outra etc. Enquanto observadores, nós podemos então individualmente ficar satisfeitos ou descontentes (segunda codificação) com a presença de tais acontecimentos.

A inovação legislativa, em oposição à inovação dos sistemas de pensamento, tem a particularidade de poder se permitir ser reflexivamente "preguiçosa". Mas essa preguiça, estando lá e persistindo, tem seu preço: ociosa, a inovação não poderá oferecer resistência às resistências que ela certamente vai suscitar. O sistema que a produziu não aprende assim, ou aprende muito pouco. E essa preguiça tem ainda um preço mais elevado se o sistema que a produziu (SPO) espera que um outro sistema (SDC) seja "coagido a obedecer-lhe"; sobretudo quando sabemos que este último utilizará (ou não) a inovação de uma forma autônoma e para se desenvolver ele próprio. Fazer "atravessar" uma inovação de um sistema de comunicação a um outro (no nosso caso, do político ao jurídico) não é uma tarefa das mais simples. Podemos facilmente fazer pouco caso de uma inovação legislativa que não se faz acompanhar de uma densidade cognitiva e de uma autocrítica: "Não se trata de uma inovação; é mais um erro grosseiro desse legislador!”. E a lei pode 
apenas responder: "talvez". Isso porque não há argumento científico para sustentar essa mudança legislativa.

Quando os atores se sentem compelidos a reagir a uma mudança legislativa, o sistema de pensamento central e dominante tem maior probabilidade de ser "encontrado" (ainda que casualmente) do que as ideias alternativas disponíveis ou do que uma ideia original. Aliás, as ideias dominantes de um sistema circulam mais abundantemente em outros circuitos (a mídia, por exemplo) que as ideias alternativas armazenadas no "estoque de conhecimento" (Berger e Luckman, 1966) de um sistema. Daí a importância, para uma inovação, de atingir e de modificar os registros mais exigentes de reflexão.

6. Retornemos agora à novidade superficial, aquela que não perturba a matriz central do sistema. Essa novidade é de certa forma "considerada" na reprodução normal como uma virtualidade: ela é considerada com um status cognitivo antecipado de reprodução normal. Por exemplo, considera-se a possibilidade que novos crimes sejam criados e que alguns crimes sejam descriminalizados. Considera-se também a possibilidade de que a magnitude das penas possa aumentar ou diminuir. A estrutura de expectativas central concebe também que certas penas possam ser substituídas por outras (e nas duas direções): pena capital por prisão, prisão por multa etc. Em todos esses casos, a compreensão "não transborda", por assim dizer, o que é observado no plano dos fatos: um novo crime que é criado, um antigo crime que se torna obsoleto ou que foi contestado com sucesso e uma pena que foi substituída por outra. Essas mudanças consideradas como possíveis fazem parte das incertezas previstas com antecedência na estrutura central do sistema. E isso se dá mesmo que não se possa prever com certeza se, quando e onde elas vão ocorrer. No entanto, a mudança introduzida pelo art. 28 não faz parte dessas incertezas antecipadas pelos sistemas de pensamento centrais.

7. O conceito de reprodução normal não explica a mudança: ele descreve o que foi atualizado com a ajuda do esquema normal/desviante para indicar que a estrutura central (com suas incertezas) foi reiterada no lugar de outras possibilidades. Esse conceito não diz que os atores são determinados por essa estrutura como se eles estivessem numa relação de causa e efeito. $O$ conceito não pressupõe também que o conteúdo da mudança seja ruim ou bom.

As expressões reprodução perturbadora, desviante ou inovadora são equivalentes. Elas simplesmente ressaltam diferentes dimensões de um mesmo fenômeno. A qualificadora "perturbadora" ressalta o efeito que a reprodução produz na matriz cognitiva central. A noção de desvio coloca em primeiro plano a ideia de uma transgressão forte das expectativas dominantes institucionalizadas. Enfim, o termo "inovadora" chama a atenção para a originalidade da mudança e seu potencial criador ainda-não-realizado. 


\section{UM PROBLEMA DE DESCRIÇÃO: O STATUS DA LEGISLAÇÃO}

Geralmente todo mundo concorda em dizer que a legislação (leis, decretos etc.) depende de operações realizadas pelo sistema político. A legislação é uma criação política. Não diríamos, por exemplo, “judge made legislation”. Poderíamos dizer “judge made law", dando a "law" o sentido de "direito" ou de normas oriundas das decisões dos tribunais, mas não no sentido de legislação ou de "Statute". Poderíamos também dizer, paralelamente, que a legislação é observada pelo SPO como sua realização. Esse ponto não é contestado. Mas qual é o lugar da legislação no sistema de direito? Digamos em princípio que a teoria dos sistemas dá um status teórico particular para a legislação no contexto das operações do sistema de direito.

A teoria dos sistemas parte da ideia que cada sistema social autopoiético produz "seus próprios elementos" com a ajuda de seus próprios elementos. Basta dizer aqui, para passar mais rapidamente ao nosso problema, que isso não significa uma negação das relações de influência, de pressão ou de força. Os sistemas de saúde ou econômico, por exemplo, podem fazer pressões levando o sistema político a criar leis. A questão para nós é a seguinte. É difícil conciliar a frase "cada sistema produz seus elementos com a ajuda de seus elementos" com a ideia geralmente aceita, inclusive pela teoria dos sistemas, que é o SPO que cria a legislação. Esta não é efetivamente também um elemento do sistema jurídico?

A teoria dos sistemas descreve a legislação como aquilo que promove um acoplamento estrutural das operações (comunicações-ações) entre os dois sistemas. Tudo se passa como se a legislação tivesse duas faces: uma voltada para o SPO, e a outra, para o sistema de direito. Ela é uma criação do SPO que serve ao mesmo tempo de "limitação exterior" (parâmetro, enquadramento) e de "fonte" (matéria-prima) para o direito a fim de que ele mesmo produza suas próprias comunicações de direito (elementos) com a ajuda de outras fontes de direito. Fontes que o sistema de direito produz dessa vez diretamente dentro do sistema como a jurisprudência e a doutrina (outros elementos comunicacionais). No entanto, o próprio sistema de direito enxerga a legislação como "exprimindo a vontade do legislador" (mensagem especial do sistema político que obedece a critérios reconhecidos pelo sistema de direito) e como uma "fonte do direito", ou seja, uma fonte para fazer emergir um direito pelo direito. A expressão "vontade do legislador" mostra que o sistema de direito atribui sem dificuldades a produção da legislação ao político. Mas, ao mesmo tempo, a teoria dos sistemas lembra que é o sistema de direito que determina, no contexto de suas comunicações e decisões, qual é efetivamente, em cada caso concreto, essa vontade do legislador.

A expressão "aplicação da lei” é portanto enganosa e não faz justiça à complexidade do que se passa globalmente no interior do sistema de direito. O conceito de "aplicação da lei" projeta a falsa imagem de uma aplicação mecânica e/ou individualizada de uma lei em particular ("o artigo da lei X”) a um acontecimento específico. 
Todavia, para o sistema de direito, “aplicar”, se quisermos manter esse termo, não significa somente isso (ou seja, colocar em execução ou não uma lei específica no sentido obedecer-lhe ou não). A expressão "aplicar a lei” deve também ser entendida como "aplicar a legislação", e portanto comparar uma lei específica a outras leis selecionadas (e não somente confrontar a lei ao acontecimento). Mas "aplicar a lei" significa igualmente produzir uma decisão que será observada pelas comunicações subsequentes do sistema como uma decisão que criou comunicação jurídica ${ }^{11}$.

Para evitar certos mal-entendidos e essas simplificações no uso da expressão "aplicação da lei”, propomos dar um lugar secundário para esse conceito e distinguir o mais claramente possível essas duas operações: a criação política das leis e a produção do direito pelo direito. A expressão “criação das leis" é preservada para descrever certas operações do SPO e a expressão “aplicação da lei” é então substituída por “produção do direito". A "lei" aparece assim, para o sistema de direito, como um médium permitindo que este determine suas formas a cada uma de suas decisões ${ }^{12}$.

Com efeito, o sistema de direito reconhece frequentemente nas leis uma razão para modificar suas decisões ou sua orientação, mas isso não esgota todas as possibilidades abertas ao sistema no sistema. Por exemplo, ele pode também julgar que a nova lei vem "consagrar" mais do que modificar suas práticas. Nesse caso, ele permanece indiferente, pois não vê "nada de novo” na nova lei. Ele pode também invalidá-la com a ajuda do tempo confrontando-a com outras leis. Ele pode igualmente colocar em prática estratégias visando a evitá-la, a contorná-la.

\section{DoIs CONCEITOS DE PUNIÇÃo NÃO SElecionados PELO SDC}

Retornemos agora à reação que a lei brasileira de drogas suscitou no SDC. Para melhor compreender a origem de uma tal reação, examinaremos o conceito de pena (punição) começando com dois exemplos de definições de punição não retidos pela matriz dominante. Voltar-nos-emos na sequência para o problema dos sistemas de pensamento, sobretudo para os sistemas alternativos. Façamos três comentários metodológicos preliminares.

Visto que nossa atenção vai recair sobre a maneira pela qual um sistema de comunicação especializado (SDC) define de forma dominante um conceito (pena), vamos em primeiro lugar levar em conta a dimensão temporal. Para fazê-lo, distinguimos dois grandes períodos: o período de formação do sistema (1050-1750) e o período do sistema constituído (1750 até o presente). Vamos em seguida isolar o século XVIII como fase de transição e de "últimas oportunidades" no plano das seleções (escolhas) antes (1) da consumação da organização das estruturas internas do sistema e (2) do começo, por assim dizer, de sua reprodução "normal” enquanto sistema já formado. Entendemos que o período de formação só é acessível à observação de forma retroativa e a partir dos parâmetros do sistema já constituídos. Enquanto 
ele se forma, nós não podemos antecipar (no tempo presente) o que ele vai efetivamente selecionar e o que ele vai excluir/não tomar conhecimento. Antes que o sistema tome uma forma diferenciada acabada, não temos um ponto de referência empírico claro para fazer a observação (retroativa) da formação das estruturas dominantes que constituíram o sistema. Devemos logo notar que o conceito de evolução refere-se usualmente ao conjunto desses dois períodos, mas que a problemática da evolução, e a forma de concebê-la, se modifica de um período a outro. No primeiro período, observamos sobretudo como o sistema se autodistingue de seu ambiente, mas também como ele assegura seu processo de autoestruturação. No segundo período, nós observamos mais o que acontece ou não acontece com as estruturas internas do sistema, sua reprodução normal ou inovadora e, entre outras coisas, como ele se relaciona, enquanto sistema diferenciado, com seu ambiente e outros sistemas (sociais e psíquicos).

Em segundo lugar, o leito não deve compreender as seleções que o sistema faz com um modelo de evolução darwiniano na cabeça. Afinal, as escolhas que um sistema opera não são necessariamente as melhores para o próprio sistema ou "para a sociedade". Os sistemas atualizam certas possibilidades entre as que estão disponíveis, mas também que são viáveis. As seleções dominantes podem então ser menos flexíveis ou insuficientemente complexas para resolver convenientemente os casos que serão tratados pelo sistema. Do ponto de vista de certas perspectivas éticas externas, as escolhas do sistema para reforçar sua própria legitimidade interna podem também ser lamentadas.

Em terceiro lugar, é preciso ter em mente que desde a invenção da escrita, as definições perturbadoras se liberam de suas limitações temporais, pois elas podem ser redescobertas durante um outro período e se tornarem mais uma vez perturbadoras. Sua "localização" (espaço de atualização) pode também se modificar. Assim, uma definição que ficou no ambiente do sistema num dado momento pode muito bem ser atualizada nas comunicações do sistema num outro momento. Ela pode também ser atualizada num tempo $\mathrm{X}$ nas comunicações do sistema simplesmente para indicar o que deveria ser excluído e retomado num tempo Y, mas desta vez de forma positiva, para indicar o que deveria ser retido ou reconsiderado.

Antes de ver o conceito de pena que foi integrado na estrutura cognitiva dominante do sistema (próxima sessão), indicaremos primeiro duas modalidades excluídas das definições de pena ou punição tendo como ponto de referência o SDC.

1. Durante a fase de transição mencionada acima (século XVIII), encontramos então uma definição da pena em Montesquieu que se destina ao direito criminal tal como ele era conhecido na época, mas que não foi todavia selecionada por esse sistema. Em Montesquieu (1748, 6L, 9C e 16C), a paz entre as partes parece ser uma solução absolutamente aceitável em direito criminal e, para ele, "tudo que a lei chama de 
pena é efetivamente uma pena" $(1748,92)$ : a simples condenação pode ser vista como uma pena $(1748,91)$, podemos dar conselhos $(1748,32)$ e podemos também pagar indenizações $(1748,103)$ à vítima. A ideia de pena está assim presente, mas não está de forma alguma substancializada, como aliás a de punição também não está.

Compreendemos então por que Montesquieu, se observasse hoje a mudança legislativa do art.28, não falaria nem de descriminalização nem de despenalização. Com efeito, com um tal conceito de pena, na sua concepção aplicável aos crimes, ele teria visto aqui apenas uma mudança (inovadora) nas penas. Para poder "ver" uma descriminalização ou uma despenalização, é preciso antes ter selecionado como pano de fundo o conceito de pena da matriz dominante. Da mesma forma, um observador que não conhece a matriz dominante não seria capaz de ver aqui uma inovação. Ele também veria apenas uma simples mudança de penas. Por outro lado, como Montesquieu provavelmente não acreditava que a diferenciação entre as justiças criminal e civil dependia de uma distinção no plano das sanções, ele não diria que essa mudança revela um projeto "de abolir" a justiça criminal ou ainda uma vontade de torná-la similar ao direito civil. Ele não compartilharia dessas suscetibilidades internas do sistema.

Conhecemos o destino dessa conceitualização. Apesar de seu interesse, ela foi criticada como "tautológica”, "circular" e sobretudo como não levando em conta a diferença entre as justiças civil e penal. Esse tipo de crítica indica uma operação de seleção já realizada pelo SDC. Essas críticas reiteram a exclusão do conceito ou seu lugar periférico nas comunicações do direito criminal.

2. Durante o período de formação do sistema, o conceito de punição ou de pena foi igualmente definido em oposição ao conceito de recompensa. Essa conceitualização vai avançar quando a recompensa começa a ser concebida como podendo ser, ela também, um tipo de sanção em direito. Facchi $(1994,17)$ indica, referindo-se ao Oxford English Dictionary, que é provavelmente Richard Cumberland, em 1672, o primeiro a empregar o termo sanção para se referir à recompensa. Ele fala então de "sanção remuneratória" em oposição a "sanção punitiva". No entanto, a comparação entre certos aspectos da recompensa e da punição é bastante antiga. Grotius (1625) também fazia comparações entre esses dois conceitos, ainda que ele não tenha chegado ao ponto, pelo que sabemos, de se referir à recompensa como sanção.

A ciência moderna vai, ela também, conceitualizar a punição em oposição à recompensa, como por exemplo no contexto das pesquisas comportamentais com os animais. Mas ela vai privilegiar outras opções que não o direito moderno. Nesse sentido, uma das modificações mais notáveis no nível das comunicações científicas concerne ao desaparecimento do conceito de "mérito". É assim que quando se estabelece a distribuição dos conceitos de punição ou de recompensa em situação experimental de laboratório, ela se faz em função da reação dos animais aos estímulos 
e não de um conceito de "mérito" qualquer. Se o comportamento "x" tende a ser inibido, o estímulo correspondente é definido como "punição"; se ele tende a aumentar de frequência, o estímulo é definido como uma "recompensa"; e se um estímulo não produz nem um nem outro efeito, ele é reputado "neutro". A definição dos termos é então baseada aqui nos efeitos comportamentais diretamente observáveis e sem referência à noção de mérito, ao esquema inocente/culpado ou ao esquema ação notável/ação normal. Na moral e no direito, por outro lado, o conceito de punição "não é válido" se se sabe de antemão que a pessoa que será punida é inocente. As comunicações do sistema não podem admitir a seleção de um conceito de punição em relação a um inocente: se essa contingência acontece, espera-se uma "correção" por parte do sistema. O mesmo princípio vale para a recompensa que é juridicamente controlada: é preciso cumprir uma ação meritória. Eis aí uma das razões pelas quais cada sistema especializado de comunicação constrói de forma diferente seus conceitos de punição e porque é pouco provável que se possa conceitualizar esses termos sem um sistema de referência.

A ética e o direito vão então se fazer algumas perguntas que são "próprias" a esses sistemas de comunicação: "por qual motivo punir ou recompensar?", "sob quais condições podemos punir ou recompensar?", "quem pode punir ou recompensar e quem pode ser punido ou recompensado?” etc. Responderemos, por exemplo, que ter cometido um crime e ser declarado culpado por um tribunal independente é uma condição para ser punido ou para falar de punição, que somente uma autoridade ou somente o direito criminal podem punir etc. Essas questões dão ensejo a todo tipo de resposta segundo as preferências de cada autor-ator. Aliás, é surpreendente constatar que as respostas e justificações morais, políticas e jurídicas que foram dadas em relação à punição foram também dadas em relação à recompensa, onde também existe um "debate" entre utilitaristas e retributivistas. A grande diferença entre os dois debates reside no próprio conceito de punição. Por exemplo, o cardeal Richelieu no seu Testamento Político - defendia que tanto a pena como a recompensa "olhavam mais o futuro que o passado" (voir Facchi, 1994, 8-9). Por outro lado, Earl of Shaftesbury via a pena e a recompensa como tendo primariamente um objetivo retributivo, o objetivo correcional sendo apenas corolário (Facchi, 1994, 19). Vemos portanto que os observadores são livres de indicar suas preferências. As teorias da pena vão condensar essas seleções e oferecê-las aos atores-tomadores de decisão como pré-seleção de suas seleções. Em todos esses casos, o conceito de "mérito" se torna central, possibilitando-nos debater se o que é mérito é obrigatório ou não. Grotius (1625) dirá por exemplo que nem o crime nem a recompensa são "devidos", no sentido de serem obrigatórios. Outros dirão que a pena é obrigatória, mas a recompensa não, etc.

Tomemos um único exemplo dessa linha de pensamento periférica (à matriz do direito criminal moderno) que define a punição em oposição à recompensa e que se 
encontra bem ancorada na metade do século XVIII. Hutcheson (1747: 329) escreve: "The sanctions of laws are rewards and punishments. Rewards have place in the civil laws as well as punishments”. Devemos notar que - caso o autor não sabote sua definição na seqüência ou não acrescente outras distinções de forma a reintroduzir a definição dominante de punição - a sua forma de definir tem as mesmas qualidades que a de Montesquieu. Com efeito, como as penas previstas no artigo 28 acima não podem de forma alguma ser compreendidas como recompensas, elas seriam efetivamente «verdadeiras penas » para Hutcheson. Mesmo certas sanções do direito civil seriam compreendidas aqui como punições dadas pelo direito civil (o que não o transformaria todavia em direito criminal).

Quando opomos a noção de punição à de recompensa, a primeira toma um sentido amplo e não substancialista, pois ela se refere em primeiro plano à mensagem da linguagem (comunicacional) que está associada à sanção e não a especificações que pressupõem que a punição tem uma "natureza própria" no mundo das sanções. Podemos multiplicar os exemplos no século XVIII nos quais o sentido das palavras "pena” e "punição" não exclui nem certas sanções do direito civil nem as penas compreendidas no artigo 28. Dessa forma, Muyart de Vouglans (1767: 50), opositor de Beccaria e jurista do Antigo Regime, emprega o conceito de "penas pecuniárias" para se referir ao mesmo tempo "ao confisco, aos juros civis, aos danos e juros assim como às custas”. Ele teria sem dúvida lamentado o abrandamento das penas, mas também não teria falado em descriminalização ou despenalização no caso do artigo 28 .

\section{Algumas ReferênCIAS históRICAS SOBRE O CONCEITO DOMINANTE DE PENA}

Retroativamente, acreditamos poder afirmar que duas grandes distinções foram inventadas e reiteradas para construir o conceito de punição: (i) a distinção recompensa/punição que acabamos de ver e (ii) a distinção reparação/punição ou ainda não intenção/intenção de infligir um sofrimento de que vamos tratar agora. É esta última conceitualização que estimula e motiva os autores-atores a falar em "descriminalização" ou "despenalização" em face do artigo 28, ou ainda a querer distinguir entre "verdadeiras/falsas penas" 13 . Essas duas grandes distinções estão presentes na doutrina e na filosofia penal, mas apenas a última será selecionada e condensada pelas teorias da pena (retribuição e dissuasão). Somente ela ocupará um lugar dominante nas comunicações científicas do direito criminal e na lei escrita.

A teoria da retribuição seleciona de maneira unívoca esta distinção reparação/punição desde o século XIII (portanto excluindo de cara outros tipos de sanções), enquanto a teoria da dissuasão parece esperar o século XVIII para adotar o mesmo conceito, também de forma unívoca. Se esta hipótese é fundada, o texto de Beccaria é paradigmático neste sentido. 
Estabeleçamos algumas referências históricas.

1. Harold Berman, numa importante obra sobre a formação da tradição jurídica ocidental na época da Revolução Papal (1050-1150), nos dá uma pista importante para compreender o nascimento da semântica punitiva (atribuição intencional do sofrimento/reparação) que vai acabar por ser dominante no SDC a partir da segunda metade do século XVIII.

Segundo Berman (1983: 172), um panfleto anônimo do século XI, De Vera et falsa penitentia, terá um impacto considerável e, acrescente-se, bastante improvável sobre certos textos religiosos e jurídicos subsequentes, começando pela teoria da expiação de Santo Anselmo. Esse texto, perturbando a maneira religiosa de ver as coisas, dominante naquela época, aproxima a poenitentia (sacramento da penitência) da poena tenere ("sofrer uma punição"). O primeiro problema, de ordem teológica, reside justamente no fato de anexar a instituição da penitência à ideia de punição. É um problema importante, mas vamos deixá-lo de lado aqui. O segundo problema vem com a modificação do conceito de punição proposto no texto. Essa definição vai trazer a distinção não intenção/intenção de infligir um sofrimento ou reparação/punição, o que tem como efeito imediato (1) reduzir o alcance do que pode contar como punição e (2) constituir uma formidável substancialização. Com efeito, se um observador opõe a punição à reparação sem levar em conta o sistema de comunicação nos quais elas se inscrevem, ele se priva da possibilidade de ver a reparação como uma "verdadeira pena". Esse tipo de distinção tende a introduzir um tipo de corte vertical entre as sanções e a dividi-las, "por natureza”, em dois grupos: aquelas que são punições e aquelas que não o são; em suma, uma formidável substancialização das sanções. $\mathrm{O}$ texto diz o seguinte:

\begin{tabular}{l|l|l}
$\mathrm{N}^{\circ}: 3$ & $\begin{array}{l}\text { «Properly speaking, punishment (poena) is } \\
\text { a hurt (laesio) which punishes and avenges } \\
\text { (vindicat) what one commits... Penance } \\
\text { (poenitentia) is therefore an avenging (vindicatio), } \\
\text { always punishing in oneself what he is sorry } \\
\text { to have done» (Lettre anonyme, citée par } \\
\text { Berman, 1983). }\end{array}$ & $\begin{array}{l}\text { Distinfligir/infligir } \\
\text { um mal }\end{array}$ \\
\end{tabular}

Observemos que nessa definição (comunicação religiosa), a punição aparece implicitamente anexada ao conceito de mérito: "punindo sempre o que o indivíduo se arrepende de ter feito". O pecado é uma condição de possibilidade para se falar em punição (ou de autopunição). 
2. Berman (1983) fornece provas suficientes para que possamos considerar a teoria da expiação de Santo Anselmo (Cur Deus Homo, 1098) como a primeira formulação da teoria retributivista no Ocidente. Segundo Berman, Anselmo conhecia bem essa carta anônima e teria incorporado esse conceito em sua teoria. É preciso todavia precisar que o conceito não é explicitamente retomado por Anselmo. Mas vê-se bem que ele opõe de forma recorrente satisfação à punição, o que deixa entrever a distinção proposta pela carta anônima. Por exemplo: "It is not right to cancel sin without compensation or punishment" (Anselme, 1098, C 12, 217, grifo nosso). Notemos contudo que Anselmo aceita ainda a compensação como uma solução alternativa à punição para expiar o pecado: ele diz reparar ou ser punido. Essa alternativa vai desaparecer na matriz dominante do SDC quando este sistema vai selecionar um conceito de punição que exclui a reparação, seja "abandonando-a" às sanções do direito civil, seja reconhecendo-lhe um status apenas complementar à punição. Segundo Anselmo (1098, 248-250), a única coisa que Deus não pode fazer, é aceitar perdoar os pecados na terra. Enquanto estiver "nesta vida", o pecador deve pagar integralmente seus pecados. Após sua morte, a misericórdia divina pode entretanto primar sobre uma justiça no sentido estrito. Há aqui o germe da ideia da obrigação de punir selecionada por Kant (1797) e pelo SDC no século XVIII.

3. Podemos ver que em Berman (1983 : 183), quando ele se refere a São Tomás de Aquino, a teoria retributivista do século XIII já faz uma distinção inequívoca entre duas situações: (i) a sanção que é para a vítima em razão dos danos; (ii) a sanção que é para os crimes (autoridade) em razão de uma injustiça especial. A teoria retributivista fecha então seu círculo. Ela (a teoria, não todos os atores-autores!) reserva doravante o termo punição para os crimes, mas opondo a punição à reparação. Para a teoria, a tarifa para um crime deve ser somente expressa sob a forma de um conceito de punição construído com a ajuda do esquema "não ter/ter a intenção de causar um sofrimento ao infrator".

Aquino devia contudo resolver certas dificuldades. Por exemplo, como justificar o fato que um ladrão seja punido e que aquele que não paga voluntariamente seu aluguel seja apenas responsável por indenizar sua vítima? Aquino (1265-74,111) vai distinguir então entre dois tipos de "deslocamento do equilíbrio" ( displacement of the balance »): os deslocamentos com/sem injustiça. Para ele, não pagar um aluguel é produzir um deslocamento de equilíbrio sem injustiça ("sine injusticia”); roubar ${ }^{\mathrm{NT}}$, por outro lado, é um deslocamento do equilíbrio incluindo uma "falta da ordem da injustiça" ("injustitiae culpa”). As normas de comportamento e de sanção são assim cindidas em dois grandes segmentos: somente a transgressão da lei criminal se torna uma "injustiça" (transgressão com culpa moral forte); a da lei civil, um desequilíbrio sem culpa moral forte (ou sem injustiça special). Não é mais toda imoralidade que é crime e que reclama punição; o crime se torna a imoralidade que a autoridade 
política distingue das outras formas de imoralidade. Eis aí a forma de diferenciação selecionada pelo direito criminal que é interna ao sistema de direito (direito criminal/outros sistemas de direito). Para o direito civil, a indenização seria suficiente, no sentido de que não haveria um preço adicional a pagar à autoridade. A "punição" certamente existe para o direito civil, mas sob a forma de um preço adicional destinado à vítima.

4. Pouco tempo depois, a distinção lei perfeita/imperfeita começa a ser atualizada para excluir a reparação como pena para os crimes. Encontramos um bom exemplo disso no comentário de Marsílio de Pádua (1275-1343) que vai ser publicado apenas em 1505: "Um exemplo [de uma lei imperfeita] pode ser encontrado em certos países bárbaros, onde se tem como norma [de sanção] justa o fato de ser desculpado e exonerado de toda punição civil [no sentido de "punição humana"] relativa a um homicídio, desde que o [o autor] pague um certo montante para tal delito" (em Il defensore della pace, 1960, 156, citado por Bobbio, 1961, 141). Se definimos o crime como um atentado à autoridade e a punição como um "hurt", torna-se então cada vez mais difícil ver o pagamento de um montante (ainda que endereçado à autoridade) como uma punição "suficiente" para uma vida.

5. Hélie (1856, xxvii) conta que, em meados do século XVI, Alphonse de Castro, um monge de Salamanca, publica um livro, De potestate legis poenalis, no qual "coloca na mesma linha, como dois atos tendo um caráter idêntico, a penitência imposta ao pecador, e o castigo infligido ao delinquente" (grifo nosso). Essas duas medidas, prossegue o autor, "punem uma falta" e "distribuem um sofrimento" que é representado como sendo proporcional à gravidade da falta. A diferença parece residir aqui no fato de que a penitência toma a forma de uma autopunição (como na carta anônima do século XI), pois é o próprio pecador que usualmente assume sua execução (imposta pela autoridade eclesiástica), enquanto a punição propriamente dita toma a forma de uma punição infligida (e não somente imposta) pela autoridade laica.

6. Essa distinção (reparação/punição) será consagrada por uma definição de punição dada por Grotius (1625, II: 373) que se tornará “clássica” e que será retomada usualmente por autores de nossa época para ratificá-la ${ }^{14}$. Grotius dirá que a punição é um "malum passionis quod infligitur ob malum actionis" ("um mal que se sofre [mal de retribuição] em razão de um mal que se fez [mal de ação]”). Vê-se bem que essa definição fundamenta ainda o conceito no esquema sofrimento/mal e remete à natureza do ato que se realiza, e não ao significado que a sanção toma num sistema de comunicação específico. Transpondo aqui os comentários de Luhmann (1984) relativos a outras definições, pode-se dizer que há aí "too much ontology"! Isso não impede que existam outros aspectos da reflexão de Grotius, não selecionados pelo SDC (como sua crítica 
da obrigação de punir), que são bastante interessantes para uma reconstrução do conceito de pena em direito criminal.

O importante aqui é nos darmos conta de que estamos diante de um longo processo de seleção e de condensação de sentido no qual o SDC vai selecionar e constituir "teorias práticas" que dirão de antemão o que é e o que não é uma punição. Não podemos deixar de notar que essas teorias tinham outras possibilidades de seleção além daquelas que foram retidas. E, enfim, tendo em vista as seleções que foram feitas, para essas teorias as penas do artigo 28 não são penas ou então são apenas penas imperfeitas.

7. No século XVIII, essa definição "retributivista” de punição será também selecionada pela teoria utilitarista da dissuasão de Beccaria e será reconduzida na versão laicizada da teoria retributivista de Kant (Pires, 1998). Em face dessa evolução, pode-se entender o que queremos dizer afirmando que as penas do artigo 28 são efetivamente uma "inovação" e que inovação não significa "originalidade" da pena enquanto tal, mas mais uma "perturbação de uma distinção dominante e institucionalizada"; perturbação da matriz cognitiva (teorias) e normativa (legislação) dominante.

\section{A Re-estabilização do CONCEITO “CENTRAL” de PENA}

O número de autores-atores dos séculos XIX e XX que reiteram (consciente ou inconscientemente) a seleção de nossa carta anônima do século XI é impressionante. O leitor que tem dúvidas neste ponto é convidado a folhear os manuais de direito criminal na Europa e nas Américas. Seguem alguns exemplos escolhidos ao acaso, ainda que eles tenham sido selecionados em função da clareza e da qualidade das definições.

1. Comecemos por certas perspectivas da filosofia moral, política e penal que se entrecruzam no plano cognitivo e que atualizaram as pré-seleções da teoria retributivista:

$$
\begin{array}{l|l}
\mathrm{N}^{\circ}: 4 & \begin{array}{l}
\text { "We have so far defined punishment as pain } \\
\text { inflicted because the sufferer has done wrong » } \\
\text { (McTaggart, 1896, 485) }
\end{array} \\
\mathrm{N}^{\circ}: 5 & \begin{array}{l}
\text { «It is an end in itself that the guilty should } \\
\text { suffer pain }(\text { Ewing, 1929, p. 13) }
\end{array}
\end{array}
$$

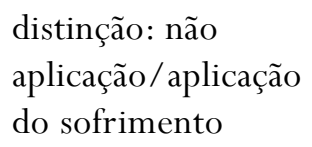

A definição de Wasserstrom é particularmente clara e bem cuidada: 


$$
\mathrm{N}^{\circ}: 6
$$

«Punishment, whatever else may be said of it, involves the intentional infliction of pain or suffering upon human beings by other human beings » (Wasserstrom, $1980: 112$ ). distinção: não aplicação/aplicação do sofrimento

Observemos que a definição de Wassertrom não é adequada para a ciência. Ela não compreende a punição infligida aos animais. Mas o autor não limita sua definição a um sistema preciso de referência. Notemos também que a "clareza" dessas três definições não elimina a incerteza de sua aplicação a casos concretos. Assim, se esses autores são confrontados ao artigo 28 acima, não podemos prever o que eles vão dizer. Eles podem, se assim o quiserem, aplicar "com sucesso" a definição deles às penas prevista, agindo assim de forma a "salvar a definição". Basta dizer que a advertência, a prestação de serviços ou a medida educativa contam aqui como punição em razão da parcela de sofrimento que eles podem de qualquer forma causar. Se atualizamos a teoria retributivista dessa forma, reproduzimos a teoria no plano cognitivo, mas adaptando-a à facticidade do acontecimento (da mudança legislativa). A teoria "não é desacreditada", sobrevive à sua decepção, sem no entanto aprender com ela: ela pode reaparecer mais tarde na sua versão mais estrita.

2. Certos juristas penalistas deram por outro lado uma definição da pena tão detalhada que eles dão a impressão de não poder ver as penas do artigo 28 como verdadeiras penas. Eis o exemplo de um célebre jurista italiano:

\begin{tabular}{l|l|}
$\mathrm{N}^{\circ}: 7$ & "Nenhuma outra definição é mais essencial \\
e mais adequada à natureza das coisas que \\
a que considera a pena como malum passionis \\
propter malum actionis. A pena é então um \\
sofrimento infligido ao autor de um crime \\
em razão do crime praticado. [...] A pena \\
tem assim um caráter retributivo, aflitivo e \\
pessoal [grifado no original]. Podemos ainda \\
acrescentar que há uma consubstancialidade \\
entre o caráter retributivo e a aflição adotada \\
como caráter fundamental da pena. Não há \\
pena [ou punição] sem caráter aflitivo, que \\
não possa traduzir uma sensação de dor, \\
ainda que esta não seja sentida [efetivamente] \\
pelo condenado. O que conta é que, na sua
\end{tabular}

Retomada da definição de Grotius (1625)

Distinção não intenção/intenção de atribuir sofrimento

Não há pena sem a impressão de causar uma dor (reparação excluída) 
razão informadora, a pena seja portadora de uma sensação de dor”(Bettiol, 1973, III, 84-85).

Hart (1968 : 4-5) adota o mesmo procedimento indicando cinco elementos constitutivos da definição de um direito criminal. No seu texto, ele faz referência a « normas legais » e ao « sistema legal" ("legal system"), sem qualificar essas normas ou sistema como sendo especificamente de direito criminal. Entretanto, torna-se claro ao longo da leitura do texto que sua definição não compreende todas as sanções possíveis. Por exemplo, as sanções de reparação são excluídas. Para ele, esse conceito se constrói assim:

\begin{tabular}{|c|c|c|}
\hline$N^{\circ}: 8$ & $\begin{array}{l}\text { "(i) It [punishment] must involve pain or other } \\
\text { consequences normally considered unpleasant. } \\
\text { (ii) It must be for an offense against legal rules. } \\
\text { (iii) It must be of an actual or supposed offender } \\
\text { for his offence. } \\
\text { (iv) It must be intentionally administered by } \\
\text { human beings other than the offender. } \\
\text { (v) It must be imposed and administered by an } \\
\text { autority constituted by a legal system against } \\
\text { which the offence is committed» } \\
\text { (Hart, 1968, 4-5) }\end{array}$ & $\begin{array}{l}\text { Exige a atribuição } \\
\text { de um sofrimento } \\
\text { Referência às normas } \\
\text { do direito } \\
\text { Condição de } \\
\text { aplicação } \\
\text { Exclusão da ação } \\
\text { do autor } \\
\text { Critério da } \\
\text { autoridade } \\
\text { constituída }\end{array}$ \\
\hline
\end{tabular}

Em relação ao artigo 28, apenas o primeiro critério coloca dificuldades. O leitor constatará facilmente que o sistema se apropria aqui de sua definição de punição (item v). Ele pode então observar a punição dos outros sistemas como um simples "fato" ou "sanção" que não conta para o sistema. Ele se apropria também de suas "ofensas", o que é uma forma de autolimitação. Não é certo que Hart falaria de descriminalização em relação ao artigo 28 , pois ele veria que os crimes permanecem como crimes para o sistema. Mas para evitar falar em despenalização, é preciso dar novamente uma certa elasticidade ao critério "i”. Dessa forma, salva-se a definição. A reparação, por outro lado, faria "explodir" o sentido do primeiro critério. 


\section{Conclusão}

Vimos que a observação da inovação no plano cognitivo e normativo não se presta facilmente ao consenso. Essa dificuldade se dá em parte ao fato de que o conceito de inovação depende não apenas da forma de estruturar a observação empírica, mas igualmente de um quadro teórico que lhe dê sentido.

No contexto de uma teoria sistêmica, podemos conceber uma ligação entre os conceitos de inovação e de evolução. Mas esses dois conceitos não são equivalentes. Retomando livremente um comentário de Luhmann e De Giorgi (1991: 175), digamos que a teoria (sistêmica) da evolução tenta descrever e explicar "as transformações da estrutura" (cognitiva e normativa). Nessa perspectiva, como escreve Neves (2006: 1) retomando Edgar Morin, "a evolução se manifesta com a transformação do improvável em provável”. Podemos acrescentar que pelo tempo que a evolução perdura, visto que ela consiste numa transformação das estruturas, ela "normaliza improbabilidades, estas sendo compreendidas como um grau de desvio em referência a um estado inicial" (Luhmann, citado por Neves, 2006, 1).

Temos aqui um problema de linguagem conceitual que está ligado ao duplo uso da palavra estrutura. Esse termo é frequentemente utilizado no singular para indicar a estrutura dominante ou de primeiro plano do sistema. Se a distinção entre dois tipos de estrutura (as estruturas de normas e os sistemas de ideias) enriquece nosso olhar empírico, o termo tomado no singular designa de forma sintética este "conjunto de estruturas" situado no centro das operações do sistema.

O conceito de inovação é menos exigente que o de evolução. Ele serve sobretudo para indicar que o que é desviante em relação a uma estrutura (central) tomada como ponto de referência inicial. O conceito de evolução, por sua vez, é muito menos global que o de inovação. Ele serve para observar o que se passa no plano das mudanças das estruturas centrais propriamente ditas. Como escreve Neves (2006: 2), retomando a perspectiva de Luhmann (1997: 454-455), "o fenômeno evolutivo só é realizado quando são preenchidas três condições reciprocamente ligadas: a variação, a seleção e a responsabilização/retenção".

A variação remete aos elementos do sistema, ou seja, à comunicação. Ela "consiste numa reprodução desviante dos elementos através dos elementos do sistema ou, dito de outra forma, numa comunicação inesperada, surpreendente" (Luhmann e De Giorgi, 1991, 189-190; Luhmann, 1997, 454). Todavia, a variação não significa ainda evolução pois «no plano das estruturas, o sistema pode reagir negativamente ao desvio" (Neves, 2006: 2).

No nosso caso, por exemplo, o que nós observamos empiricamente como variação são as surpreendentes comunicações sobre o conceito de pena, comunicações que circulam no sistema ou no seu ambiente. Notemos que é possível, mas relativamente complicado, falar de ideia inovadora quando ela não foi ainda selecionada, quando ela ainda não produziu, no sistema, o efeito de inovação em suas estruturas 
centrais. Ela está mais para uma ideia alternativa, para um ponto potencial de bifurcação que é apenas potencialmente inovador. Estamos situados aqui no plano da complexidade, da contingência e da livre circulação de ideias. Mas a "variação" não será necessariamente selecionada pelo sistema para fazer parte de suas estruturas centrais. Tudo isso é uma questão de observação empírica.

O conceito de seleção, no contexto específico da teoria da evolução (da teoria dos sistemas autorreferenciais), concerne à estrutura central do sistema. Quando um elemento inovador presente na comunicação toma a forma de uma estrutura, ele se torna uma expectativa generalizada que orienta a partir de então as comunicações subseqüentes. (Luhmann e De Giorgi, 1991: 190). A seleção de estruturas favorece então “a continuidade da reprodução do elemento inovador" (Neves, 2006: 2). Mas essa segunda etapa (seleção) não conclui o processo evolutivo: uma seleção pode não resistir pelo tempo suficiente que permita ao sistema generalizar essa seleção e concluir sua evolução.

No nosso caso, a mudança legislativa que observamos é empiricamente uma modalidade de seleção. Enquanto tal, essa mudança se tornou uma expectativa (normativa) generalizada que orienta doravante certas comunicações do sistema no plano normativo-decisional (por exemplo, os tribunais), assim como no plano propriamente cognitivo e reflexivo (a doutrina, por exemplo). "Orientar" não significa "aceitar", mas "servir de matéria-prima”, "motivar”, "estimular”. Essa mudança favorece sem dúvida alguma "a continuidade da reprodução do elemento inovador" (Neves, 2006: 2) no sistema (político), mas não a garante. O sistema pode ainda rejeitar essa seleção, ignorá-la após a primeira seleção ou impacto ou ainda circunscrevê-la de forma a evitar que ela "contamine” outras operações ou pontos da estrutura central.

Numa vertente, essa mudança legislativa é uma variação (comunicação) que foi selecionada (pelo sistema político) para produzir uma inovação na estrutura legislativa. Podemos então falar, tanto em sentido teórico estrito como também em sentido empírico, em inovação (resultado inovador). Essa inovação é uma operação do sistema político. Mas como ela se situa na legislação (e não nos sistemas de pensamento), ela produz ao mesmo tempo, mas numa outra vertente, um impacto especial nas estruturas (normativa e cognitiva) do sistema de direito. Se partirmos do ponto de vista do SDC, e mais especificamente de uma evolução de patamar de suas estruturas internas, torna-se interessante observar a maneira pela qual esse sistema de direito vai receber essa inovação no plano cognitivo e reflexivo. Afinal, ele não pode "produzir a legislação" em sentido literal. Ele pode apenas "propor" outras sanções como as do artigo 28 para outros crimes. Mas para fazê-lo, ele deve "refletir" e "aproveitar dessa ocasião para aprender" no plano dos sistemas de pensamento.

É por essa razão que Luhmann e De Giorgi (1991: 217) sustentam que "com a seleção, nenhum sistema autopoiético pode nem começar nem terminar uma transformação da estrutura [central]”. Ele não pode começar sem uma variação nas comunicações; 
variação que, expressa no plural, toma sempre mais o status de uma "reprodução normal”. Se, num primeiro tempo, essa reprodução se opera no plano exclusivo da variação, um sistema autopoiético pode - baseando-se nesse "primeiro tipo" de reprodução - inscrever uma inovação pontual na estrutura. É o que aqui observamos, ainda que não possamos falar "de uma transformação da estrutura”. No nosso caso, ainda que considerando a legislação criminal como uma estrutura de normas, seria de fato demasiado presunçoso considerar essa inovação do artigo 28 uma "transformação dessa estrutura". Cumpre-nos lembrar aqui que o alcance de uma inovação é frequentemente limitado.

Finalmente, o conceito de re-estabilização designa, na teoria dos sistemas, a etapa mais exigente do processo de evolução: a retenção da seleção. Como escrevem Luhmann e De Giorgi (1991: 239), "não faz muito sentido falar de uma terceira função evolutiva antes que o evento da seleção se oriente em direção a condições estáveis que seriam perturbáveis apenas ocasionalmente”. A re-estabilização se refere ao fato que o sistema assegura subsequentemente a certas inovações (seleção) "duração e capacidade de resistência". Isso implica, no nosso caso, uma solidificação cognitiva e reflexiva da inovação nos sistemas de pensamento dos sistemas autoreferenciais em questão, assim como uma reiteração e uma generalização da inovação. Na sua fase de re-estabilização, a inovação perde então progressivamente seu efeito "surpreendente" para ser solidificada e estabilizada. De qualquer forma, no plano empírico, tudo parece indicar que o conceito de inovação parece mais apropriado para designar uma observação do que se passa na etapa de seleção; ainda que não possamos reservar seu emprego apenas a essa etapa.

Se o conjunto dessas reflexões é aceitável, observamos aqui uma seleção inovadora (reprodução desviante) na estrutura da legislação criminal relativa às penas. Mas, reiteremos uma última vez, essa mudança legislativa não vincula de forma alguma o porvir do direito criminal.

NOTAS

1 Artigo publicado originalmente em francês, pela revista eletrônica Champ Pénal: Álvaro P. Pires e Jean-François Cauchie, “Um cas d'innovation 'accidentelle' en matière de peines: une loi brésilienne sur les drogues”, Champ Pénal, Seminário disponibilizado em 28 de setembro de 2007. URL : http://champpenal.revues.org/document1541.html

2 Optamos por esse acrônimo para evitar uma confusão com "sistema penal" (confusão que a sigla SP poderia suscitar). 
3 Lei disponível no site: https://www.planalto.gov.br/ccivil_03/_Ato2004-2006/2006/Lei/L11343.htm.

4 Nas seções 5 e 6 veremos que este conceito foi selecionado e reestabilizado tanto pela doutrina do direito criminal quanto pela filosofia (quando esta se refere ao direito criminal). $\mathrm{O}$ mesmo ocorre com relação à jurisprudência, mas essa ilustração não será apresentada aqui.

5 Os tribunais devem "esperar" a recepção de um caso para reagir, mas a doutrina não tem essa dificuldade.

6 No $§ 1$, a lei emprega também o termo "medidas", mas o termo "pena" é empregado no título do capítulo, no caput do artigo 28 e é retomado no $§ 3$ para se referir às mesmas sanções.

7 A questão que permanece aberta aqui é saber se uma «inovação » puramente objetiva pode contar como inovação ou, ao contrário, se é preciso, além disso, que o sistema que inova observe sua própria conduta como inovadora. A análise científica deve se dar um certo grau de liberdade em relação ao que é atualizado. Postulamos então que a percepção de inovação não é uma condição para a inovação: esta pode ser casual e até mesmo passar despercebida enquanto inovação.

8 Ver sessões 5 e 6 abaixo.

9 A origem da modificação é provavelmente inapreensível, mas a modificação legislativa é o ponto de partida de nossa observação, do que somos capazes de ver.

10 Voltaremos a essa questão (seção 7).

11 Certamente, isso não impede o sistema de rever ou de invalidar suas próprias decisões.

12 Sobre o conceito de médium/forma na teoria dos sistemas, ver Luhmann (1971, 1992). Para uma transposição em direito criminal, ver Pires(2007).

13 Sobre este ponto, ver Cauchie (2005); Cauchie, Kaminski (2007).

NT Roubar aqui deve ser compreendido de forma não técnica, ou seja, no sentido lato usado em língua portuguesa (subtração de um bem) e não no sentido jurídico (subtração de um bem mediante violência ou grave ameaça). Trata-se da tradução do verbo "voler”, que tem um caráter bastante amplo.

14 Certos autores representando um sistema de pensamento minoritário vão criticá-la. Por exemplo, Del Vecchio (1951).

\section{REFERÊNCIAS BIBLIOGRÁFICAS}

ANSELME, Saint.Cur Deus Homo. Chicago: Open Court Publishing, 1903 (1098).

BACHELARD, G. Epistémologie, textes choisis par D. Lecourt. Paris :PUF, , 1974..

BECCARIA, C. Des délits et des peines. Paris : Flammarion, 1991 (1764).

BENTHAM, J. Théorie des peines et des récompenses. Bruxelles: SBL, , 1840 (1775)..

BERGER, P., LUCKMANN, T. The social construction of reality: a treatise in the sociology of knowledge. New York:

Penguin Books, 1966.

BERMAN, H. Law and Revolution. The Formation of the Western Legal Tradition. Cambridge: Mass, Harvard University Press, , 1983.

BETTIOL, G. Diritto penale: parte generale, 8. Padova: Ed. riveduta e aggiornata,CEDAM, XXXIII, 877, $1973 .$.

BOBBIO, N. Il positivismo giuridico (Legal Positivism). Torino: Giappichelli, , 1961.

BONNEVILLE, de Marsangy A. De l'amélioration de la loi criminelle, vol. 2, Paris, 1864.

CAUCHIE, J.-F. Un système pénal entre complexification et innovations. Le cas ambivalent des travaux communautaires belges, Déviance et Société, vol. 29, n4, 2005. p. 399-422. 
, KAMINSKI, D. Éléments pour une sociologie du changement pénal en Occident. Eclairage des concepts de rationalité pénale moderne et d'innovation pénale, Champ Pénal, mis en ligne le 18 janvier 2007, URL : http://champpenal.revues.org/document613.html.

DEL VECCHIO, G. La justice - La vérité. Essai de philosophie et morale. Paris:Dalloz, , 1955.

RICHARD, Dubé. Éléments de théorie sur les commissions de réforme du droit et l'innovation cognitive en matière de justice pénale : contributions conceptuelles de Michel Foucault et de Niklas Luhmann. Champ pénal / Penal field, nouvelle revue internationale de criminologie [En ligne], Séminaire Innovations Pénales, mis en ligne le 28 septembre 2007, Consulté le 23 février 2011. URL : http://champpenal.revues.org/694. EWING, E.C. The Morality of Punishment, Kegan Paul, Trench, Trubner, London, 1929.

FACCHI, A. Diritto e ricompense. Ricostruzione storica di un'idea. Torino : Giappichelli, , 1994. GROTIUS H. de G. Le droit de la guerre et de la paix, 3 vol. Paris : Guillaumin, , 1867 (1625). HART H.L.A. Punishment and Responsibility. Oxford: Oxford University Press, 1968. HUTCHESON, F. A Short Introduction to Moral Philosophy. Glasguae, 1747.

KANT, E. Métaphysique des mœeurs, Première Partie : Doctrine du droit. Paris : Vrin, 1979 (1797).

KRAUSE, D. Luhmann-Lexicon. Suttgart: Lucius \& Lucius, 2001.

LUHMANN, N. Meaning as Sociology's Basic Concept, in : Luhmann N (dir.), Essays on Self-reference. New York: Columbia University Press, New York, 1990 (1971), p. 21-79.

Social Systems. California: Stanford University Press, 1995 (1984).

Le droit comme système social, Droit et Société, 1989, Vol. 11-12, 53-66.

Einführung in der Systemtheorie. Heidelberg: Carl-Auer-Systeme Verlag, 1992.

. Die Gesellchaft der Gesellschaft, Frankfurt, 1997.

DE GIORGI, R. Teoria de la Sociedad. Mexique: Triana Editores, 1998..

MCTAGGART, J.M.E. Hegel's Theory of Punishment, International Journal of Ethics, 1896, vol. 6, 479-502.

MONTESQUIEU, Ch. S. De l'esprit des lois. Paris : Garnier, 1973 (1748) ..

MORIN, E. La Méthode. Paris : Seuil, , 1977,.

MUYARD DE VOUGLANS, M. Réfutation des principes hasardés dans le "Traité des délites et des peines ". Lausanne: Desaint Librairie, 1767..

NEVES, M. Entre Têmis e Leviatã: Uma Relação Difícil O Estado Democrático de Direito a partir e além de Luhmann e Habermas. São Paulo: Martins Fontes, , 2006..

PIRES, A.P. Aspects, traces et parcours de la rationalité pénale moderne.In: Debuyst C., DIGNEFFE, F., PIRES, A.P. Histoire des savoirs sur le crime et la peine.Vol. 2: la rationalité pénale et la naissance de la criminologie. Ottawa: De Boeck Université, Ottawa, 1998, p.3-52.

.La línea Maginot en el derecho penal : la protección contra el crimen versus la protección contra el príncipe". In Revista Brasileira de Ciências Criminais, vol. 12, n 46, jan-fev, 2004, p. 11-45.

"A racionalidade penal moderna, o público e os direitos humanos". In Novos Estudos CEBRAP, n ${ }^{\circ}$ 68, março de 2004, p. 39-60.

. "Direito Penal e orientação punitiva: um problema só externo ao direito?". In Globalização, Sistema Penal e Ameaças ao Estado Democrático de Direito. Maria Lúcia KARAM (org.). Rio de Janeiro: Lúmen Júris, 2005, p. 191 a 220.

. Réflexions théoriques et méthodologiques sur le transfert de valeurs : le cas du droit criminel. In: GOYER, N., GIN, P., MOSER, W. (dir.). Transfert: explorations d'un champ conceptuel. Ottawa: Presses de l'Université d'Ottawa, 2007..

, GARCIA, M.. Les relations entre les systèmes d'idées : droits de la personne et théories de la peine face à la peine de mort.In : CARTUYVELS, Y., DUMONT, H., OST, F., VAN DE KERCHOVE, M., VAN DROOGHENBROECK, S. (dir.). Les droits de l'homme, bouclier ou épée du droit pénal ?. Belgique: Facultés universitaires Saint-Louis et Éditions Bruylant, 2007..

WASSERSTROM, R. Philosophy and Social Issues. Notre Dame: University of Notre Dame Press, 1980. 
Alvaro P. Pires

25 University Street Ottawa, Ontário, Canadá K1N 6N5 alvaro.pires@uottawa.ca

25 University Street Ottawa, Ontário, Canadá K1N 6N5
Jean-François Cauchie

Professor adjunto, Departamento de Criminologia, Université d'OtTAWA, Canadá

jean-francois.cauchieluottawa.ca 
